\title{
A Survey of Pre-Service English Teachers' Reading Habits of English Text
}

\author{
Alan Jaelani ${ }^{1}$ and Fadia Holisah ${ }^{2}$ \\ ${ }^{1,2}$ English Education Program, Universitas Ibn Khaldun \\ 12alan.jaelani@uika-bogor.ac.id ${ }^{2}$ fadiaholisah@gmail.com
}

\begin{abstract}
Reading should become a habit for pre-service English teachers. The habit makes a significant contribution to both academic and teaching performance. The purpose of this study was to determine the habit of reading English texts for pre-service English teachers. Data was collected through surveys and validation interviews. Questionnaires were distributed to 42 students of English Education at a university in Bogor, West Java, using a random sampling technique. This study found that the preservice English teachers' reading habits are not in the excellent category. Based on data analysis, it can be said that they have been reading English texts for more than 12 years. However, it turned out that during more than that period, they were not used to reading well, and some of them had expressed not having a good habit of reading English texts. They do not read English texts regularly; they tend to read Indonesian texts more often. Some obstacles were identified in reading English texts, such as not being used to reading for a long time and lacking vocabulary. On the other hand, they have a goal in reading, one of which is to increase their knowledge and English skills. This goal can be achieved by reading English texts regularly. They plan to read English texts regularly and ensure positive beliefs motivated by themselves for the goals they want to achieve.
\end{abstract}

Keywords: Reading Habits, Pre-Service Teachers, English Teachers

\section{Introduction}

Everyone will naturally learn one language to communicate with others. Learning to communicate only needs to imitate other people, then automatically they can communicate; however, learning to read cannot be automatically imitated instantly (Iftanti, 2012). There is a way to get information from something written; namely by reading (Dewi \& Prawita, 2019). Reading must be learned intentionally because in the process of reading there must be someone who teach. Dewi and Prawita (2019) assume that the key to improve the quality of education is reading. Reading can increase human knowledge. Therefore, reading becomes very important for students to acquire new knowledge in changing the world of the technological era (Chettri \& Rout, 2013). Reading is the art of interpreting printed and written words, the most effective process of conscious learning that affects the level and accuracy of information, morals, beliefs, judgments, and readers' actions (Chettri \& Rout, 2013). Reading activities are considered a habit if they are done repeatedly, frequently and regularly.

As pre-service English teachers, it is necessary to develop good habits in reading English texts because they will be directly involved in the practice of reading English. To have effective teaching, being a reader is an initial must for a teacher. According to (Gambrell, 2015) reading skills are related to better and more productive academic skills, social life, and citizenship. Therefore, good reading habits are very important for the development of personality and mental capacity (Annamalai \& Muniandy, 2013). According to Grabe and Stoller (2012), the habit of reading is indispensable for intellectual development that grows together and to achieve one's language skills. Thus, reading habits must be built from an 
early age because good reading habits are not acquired instantly. This shows that everyone should be motivated to have the habit of reading to improve their personality and social environment. Reading is an important tool for lifelong learning for all students and is one of the most important components of learning (Chettri \& Rout, 2013).

The ability to read is at the heart of life-long independent education. Reading is not just about pleasure but necessity, which is the basic tool of education. That is the foundation on which children's buildings must be built (Chettri \& Rout, 2013). Therefore, reading habits must be nurtured and developed (Dewi \& Prawita, 2019). In the context of education in Indonesia, students generally learn English and are involved in reading English texts for at least 12 years (Elementary-Middle-High School). According to Dewi and Prawita (2019) home will be an important environment for younger readers. Parents as supporters who best understand their children will be the main key to developing their reading interest. However, if children do not see that their family members at home have reading habits, they may find it more difficult to instill a desire (interest) to read (Dewi \& Prawita, 2019).

In addition to increasing critical thinking capacity, reading can increase and even develop creativity levels (Chettri \& Rout, 2013). This is one of the reasons why pre-service English teachers are very important in getting used to reading English texts. There are still many preservice teachers who have difficulty starting teaching practices in schools, such as bridging the gap between their pre-teaching views on teaching and the reality of teaching. Therefore, it is very important for pre-service teachers to promote good reading habits. This is a support for pre-service teachers who will later become practitioners (real teachers).

Teachers have an important role in the learning process of their students. Thus, reading activities by repeating the practice of reading English texts will become a daily activity or habit, especially for students majoring in English Education. Thus, the habit of reading is an important tool for the development of personality and mental capacity of individuals (Chettri \& Rout, 2013); with repeated reading behavior by students majoring in English Education will certainly be able to improve reading habits that are better accompanied by the development of individual personality and mental capacity, therefore this study was conducted in order to determine the reading habits of students.

For pre-service English teachers, English has become a second language, so English teachers should pay more attention to their students, interact more closely. However, (Suryati, 2015) argues that teachers in Indonesia only spend most of their time teaching in classrooms. This makes teachers and students less likely to interact, which means that most teachers pay less attention to students' mistakes; they tend to show minimal awareness of student learning. This will have an impact on improving student learning outcomes. It can be analogized that if teachers are not serious in teaching, how can students be serious in learning. In essence, a teacher is someone who will be used as an example by students. English teachers can also develop and adapt teaching materials for students with a little extra time, motivation, creativity, and love (Ramírez Salas, 2011). Therefore, the importance of the quality of an English teacher must be well prepared, especially for teaching reading English texts, because English is not their mother tongue. According to Pehlivan et al (2010), one of the efforts to develop reading habits and skills of prospective teachers is through the techniques and strategies contained in the literature and prospective English teachers are given the task of analyzing research essays, so that the quality of English teachers is getting better. Thus, teachers who are involved in the reading process will be motivated to read more, because readers will be more knowledgeable, and will also be more socially interactive about what they read. As pre-service teachers who have good quality in teaching and learning activities in the classroom, this will help students develop reading interest.

In Iftanti's (2012) it was proven that most EFL students were not indicated to have good English reading habits. Thus, this article aims to determine the habit of reading English texts among students majoring in English Education. In addition, this study also seeks to find out the purpose of reading English texts for students of the English Education study program, 
their motivation to read English texts, and their beliefs about reading English. This article is intended to find out the habit of reading English texts among students majoring in English Education. In addition, this study also seeks to find out the purpose of reading English texts for students of the English Education study program, their motivation to read English texts, and their beliefs about reading English.

\section{Research Methoodology}

A case study is described as an intensive and systematic investigation of an individual, group, community or other unit in which the researcher examines in-depth data relating to several variables (Heale \& Twycross, 2018). Researchers describe how case studies examine complex phenomena in natural settings to increase understanding of them. Furthermore, while explaining the steps to take when using a case study approach, this research method allows the researcher to take a complex and broad topic, or phenomenon, and narrow it down to manageable research questions. By collecting qualitative or quantitative datasets about the phenomenon, the researcher gains much deeper insight into the phenomenon than would be obtained by using only one type of data (Heale \& Twycross, 2018). This research was conducted by collecting data based on questionnaires and interviews. Questionnaires and interviews are one of the types of data collection that exist in qualitative research methods. Qualitative research methodology is considered suitable for researchers investigating areas of study that reveal facts or intend to ascertain and theorize salient problems (Danandjaja, 2014). This qualitative method is taken from data which is then explained by relevant theories, to produce a theory that strengthens the previous theory, therefore in this study the researchers try to reveal the truth about the reading habits of pre-service English teachers.

The participants are 42 students who are active as students of the Department of English Education at one of the universities in Bogor who will be selected to be involved in this research. In determining respondents to fill out the questionnaire, this study used random sampling. Random sampling is a sample that allows every item of the universe to have an equal chance of being present in the sample (Etikan, 2017). Thus, all students of English education have the same opportunity to be the research sample. They previously had to be active in lectures. This is important because the aim of this study is to explore the habits of pre-service English teachers in reading English texts.

This study used a questionnaire survey adapted from (Iftanti, 2012). The researcher gave a questionnaire with six question themes. Each theme is given more detailed questions. This study also uses a Likert scale in data collection. The Likert scale is a scale that shows how strong the level of agreeing or disagreeing with a statement. Respondents filled out questionnaires with statements provided by researchers about reading habits in English. The questionnaire category includes the length of time which includes reading habits, types of text commonly read, the number of books to be read, the purpose of reading English texts, motivation to read English, and beliefs about reading English. When the questionnaire data has been collected, the researcher begins to analyze it by arranging the answers from the respondents neatly. Next, the researcher will draw conclusions and verify the data. This activity aims to summarize responses regarding the reading habits of English education students, which is a case study at a university in Bogor.

The researchers then conducted interviews with four respondents who had answered the questionnaire. The four respondents selected for interview were selected based on the observations of the researchers. The categories of respondents are: 1) Students who are diligent and active in both academic and non-academic fields; 2) Students who are more diligent and active in non-academic fields; 3) Students who are diligent and active only in an academic field; 4) Students who are less active, both in academics and non-academics. Researchers asked about their habits in reading English texts. The type of interview used in this study is a persuasive interview. Persuasive interviews function to influence the way respondents think, believe and act. The researchers collect all the explanations given by the 
respondents, analyze data by sorting the answers from the informants, verify the data and draw conclusions. This activity aims to summarize the habits of pre-service English teachers in reading English texts as a case study at a university in Bogor.

\section{Findings and Discussion}

The result of the study shows English reading habits of English Education department students, their purpose of reading English texts, their motivation to read English and indicators of English reading habits of good English Education department students. Data about the English reading habits of English Education department students are reflected in the length of reading habits, the types of text, the number of books, the purpose of reading English texts, motivation and confidence in reading English, and the claims of reading habits in English.

Table 1. The Length of Time has the Habit of Reading English Text

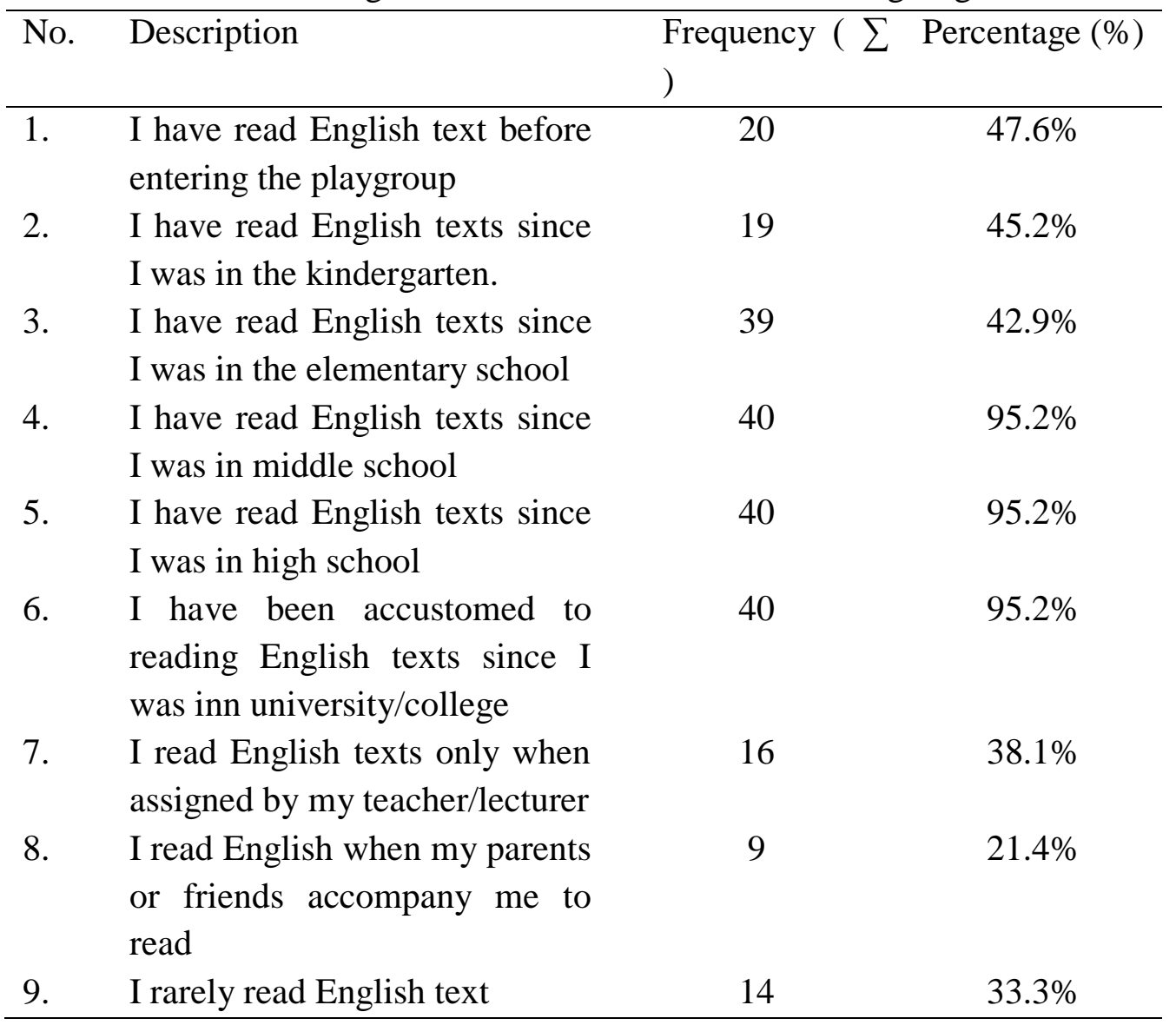

Data obtained from the length of time that they have the habit of reading English texts, statistical data (see Table 1) shows that the majority of respondents $(95.2 \%)$ have read English texts since high school, and it turns out that only $21.4 \%$ of respondents read English texts. when parents or friends accompany reading. This shows that the majority of respondents read English texts because of their obligations at school, especially in middle school, and only a small proportion of respondents read English texts during their spare time accompanied by their parents or friends.

Table 2. The Types of English Text

\begin{tabular}{llcc}
\hline No. & Description & Frequency $\left(\sum\right.$ & Percentage (\%) \\
& \multicolumn{1}{l}{ ) } & & \\
\hline 1. & $\begin{array}{l}\text { I read various types of English } \\
\text { texts }\end{array}$ & 36 & $85.7 \%$ \\
2. $\quad$ I only read nonfiction type & 14 & $33.3 \%$
\end{tabular}


English texts such as newspapers, magazines, letters, diaries, textbooks on various topics, travel brochures, and advertisements

3. I only read fiction-type English texts such as drama texts, short stories, novels, comics, legends, fables, and poetry

4. I read a lot of electronic texts in 26 $61.9 \%$ my daily English reading practice

Regarding the data obtained from the types of English texts, statistical data (see Table 2) show that the majority of respondents $(85.7 \%)$ read various types of English-language texts. However, there are only $3.33 \%$ of respondents who only (always) read nonfiction in English. This shows that students' lack of reading interest in news sources that use English. It can be concluded that the respondents are more interested in reading various types of English. This can be a benchmark for lecturers to provide English text types to pre-service English teachers.

Table 3. The Number of English Books or Article

\begin{tabular}{llcc}
\hline No. & Description & $\begin{array}{c}\text { Frequency }\left(\sum\right. \\
\text { Percentage (\%) }\end{array}$ & \\
\hline 1. & $\begin{array}{l}\text { I read one English article every } \\
\text { day }\end{array}$ & 7 & $16.7 \%$ \\
2. $\quad \begin{array}{l}\text { I read three to five English } \\
\text { articles in one week }\end{array}$ & 15 & $75.7 \%$ \\
3. $\quad \begin{array}{l}\text { I read three English books in } \\
\text { one week }\end{array}$ & 27 & $64.3 \%$ \\
4. I read less than three English \\
books in one week
\end{tabular}

Regarding the data on the number of books and articles (see table 3), the majority of respondents, namely 27 people $(64.3 \%)$, read less than three books in one week. There are only about $(7.1 \%)$ of students in the English Language Department who read three books in English in one week. This provides an illustration that respondents are very poor in reading articles and books.

Table 4. The Purpose of Pre-Service English Teachers in Reading English Text

\begin{tabular}{llcc}
\hline No. & Description & Frequency ( $\sum$ & Percentage (\%) \\
\hline 1. & $\begin{array}{l}\text { I read English texts for my } \\
\text { pleasure }\end{array}$ & 31 & $73.8 \%$ \\
2. $\quad \begin{array}{l}\text { I read English texts to do the } \\
\text { assignments }\end{array}$ & 35 & $83.3 \%$ \\
3. I read English texts to improve \\
$\quad$ my skills in English
\end{tabular}


4. I read English texts to increase my knowledge

5. I read English texts to spend 24 $57.1 \%$ my free time

The purpose of English education department students to read English texts can be seen from the statistical data (see table 4), this data show that almost all respondents (97.6\%) have a purpose of reading English texts to improve their ability in English. Of course, they have high motivation to learn English.

Table 5. Student Motivation in the English Education Department to Read English Text

\begin{tabular}{|c|c|c|c|}
\hline No. & Description & Frequency $\left(\sum\right.$ & Percentage $(\%)$ \\
\hline 1. & $\begin{array}{l}\text { I read English texts by } \\
\text { searching for the sources } \\
\text { independently }\end{array}$ & 36 & $85.7 \%$ \\
\hline 2. & $\begin{array}{l}\text { I read English texts because my } \\
\text { parents support me to read }\end{array}$ & 19 & $45.2 \%$ \\
\hline 3. & $\begin{array}{l}\text { I read English texts because my } \\
\text { friends also read English texts }\end{array}$ & 20 & $47.6 \%$ \\
\hline 4. & $\begin{array}{l}\text { I read English texts because my } \\
\text { teacher/lecturer supports me to } \\
\text { read }\end{array}$ & 36 & $85.7 \%$ \\
\hline 5. & $\begin{array}{l}\text { I don't have motivation to read } \\
\text { English texts, because my } \\
\text { English is difficult. }\end{array}$ & 6 & $14.3 \%$ \\
\hline 6. & $\begin{array}{l}\text { I read English texts even } \\
\text { though it's difficult }\end{array}$ & 38 & $90.5 \%$ \\
\hline 7. & Reading is my hobby & 26 & $61.9 \%$ \\
\hline
\end{tabular}

Almost all respondents (90.5\%) continued to read English texts (see table 5), even though it was difficult. On average respondents look for sources to read themselves $(85.7 \%)$, the motivation to read English texts arises from within them. It also revealed that $(85.7 \%)$ lecturers strongly support their students to read English texts. $61.9 \%$ of respondents said that reading English texts is based on their hobbies. Thus, it shows that the biggest motivating factor for students of the English education department to read English texts is from themselves and their lecturer support.

Table 6. Beliefs of Read English Text

\begin{tabular}{llcc}
\hline No. & Description & $\begin{array}{c}\text { Frequency ( } \sum \\
\text { Percentage (\%) }\end{array}$ \\
\hline 1. & $\begin{array}{l}\text { I believe that reading English } \\
\text { texts can improve my English } \\
\text { skills }\end{array}$ & 42 & $100 \%$ \\
& $\begin{array}{l}\text { I believe that reading English } \\
\text { texts can improve my } \\
\text { knowledge }\end{array}$ & $100 \%$ \\
& $\begin{array}{l}\text { I believe that reading English } \\
\text { texts can support my future } \\
\text { career }\end{array}$ & 38 & $90.5 \%$ \\
\end{tabular}


4.
I believe that reading English
texts can support the success of
my study

The lack of belief in reading English texts will make readers lazier because they feel uncomfortable reading. However, if the reader feels comfortable when reading, then the reader will enjoy it and it can become a habit. This is in line with the report in (Iftanti, 2012) that in order to develop their reading habit they can take time to read in a relaxed manner, that is, in comfortable conditions. Therefore, belief in reading can affect the reading habits of English education department students in reading English texts, (see table 5). It shows that all respondents $(100 \%)$ have positive beliefs in reading English texts, they believe that reading texts can improve their English skills and increase their knowledge simultaneously. See table 6, they also believe that reading English texts can support the success of their study (95.2\%) and $90.5 \%$ of respondents believe that reading English texts can support their careers in the future. This proves that those who believe in reading English texts will have positive beliefs in English conversation. Positive beliefs about reading English texts can support their own motivation for reading English texts.

\section{Indicators of Reading English Text Habits of Pre-Service English Teachers}

To investigate the habits of English Education department students in reading good English texts, the researcher interviewed four respondents who were considered to have the potential to develop good English reading habits. During the interview process, the researcher asked several questions that were not in the questionnaire, namely about the daily calculation of reading English texts, because the researcher believes that if the reader has a daily calculation of reading frequently, it can be said to be a good reading habit. This is in line with OwusuAcheaw and Larson (2014) that good reading habits are a strong weapon for students to excel in life. Then the next question is about the respondent's desire to fulfill the reading source, the researcher argues, if the respondent meets directly with the reading source it means that the respondent has read a lot of various types of reading in English. This is also in line with Owusu-Acheaw and Larson (2014) that reading habits are a planned and intentional learning pattern that can determine student academic achievement. Reading and academic achievement are interrelated and dependent on each other. So, by adding your own reading sources, you will read more often and have good reading habits. The next question that the researcher asks is about the plan to read English texts regularly, the researcher argues that if the respondent already has a plan to read the English text, it means that the respondent will try to take the time to read the English text on a regular basis because the respondent is already interested in reading. this can lead to good reading habits. This is in line with Palani (2012) that effective reading is an important path of effective learning and reading is interrelated with the educational process so that educational success requires successful reading habits. Respondents also agree that having good English reading skills will result in good academic achievement. The final question posed by the researchers is regarding selfclaims in reading the text in English, the researchers argue that this is an important thing because this concerns awareness and confidence in each respondent's self in reading English text. The results of the study that show there are indicators for English education students in reading English text. They have a strong desire to read English texts by fulfilling their reading sources personally. They also have a high motivation to read English texts despite finding it difficult, as they have positive beliefs about reading English texts. They have not been able to put the best possible time into their daily lives to read English texts, besides they have a strong interest in reading English texts regularly. They also claim that they do not have the habit of reading good English.

The desire to read English texts is very important for everyone. During the interview, all respondents stated that they have a desire to read English texts. Especially, as a pre-service 
English teacher it is very necessary to have a strong desire to read English texts on a daily basis. This is illustrated from one of the respondents' quotes, as follows:

Excerpt 1:

"Yes, I have a desire to read English texts, not only limited to doing the task, but also want to read English texts that have a genre of romance or adults." (Student A).

\section{Excerpt 2:}

"Yes, I have the desire to read English texts and am very interested in doing so." (Student B).

Reading as a pleasure, by choosing what type of text will have a positive impact on the reader. The pleasure will give an effect to the length of time when reading, this is confirmed by the report from

Owusu-Acheaw and Larson (2014) reading paving the way for a better understanding of one's own experience, it can be an exciting journey for self-discovery. So, when reading has become an exciting thing, it will affect reading time. This is illustrated by researchers from the respondent's quote, as follows:

Excerpt 3:

"I can read English texts three to five times a day. Usually I read English texts from articles, novels, and quotes on Instagram." (Students B).

\section{Excerpt 4:}

"I read English texts for one to two hours a day. Counted, 4 times a week." (Students C).

\section{Excerpt 5: \\ "I usually read English texts up to three times a week." (Students D).}

The length of time they read each day indicates the type of text and their desire to fulfill the reading source. This is in line with Owusu-Acheaw and Larson (2014) that to know about the world and its environment, a child helps himself through reading books, newspapers and other magazines. After the child is taught to reading and has developed a love for books, he can explore on his own experience and knowledge through reading. Therefore, the length of time that has been spent reading can affect the sources of reading that are read. It was observed from the quotations of students A, B, and D, as follows:

Excerpt 6:

"Yes, I have a desire for reading sources, like novels, because that is what I am interested in. For reading sources like e-books, I don't like it much." (Student A).

\section{Excerpt 7:}

"Yes, I have the desire to fulfill reading resources, such as the library or others. Currently I am finishing English novels. I also have a stock of English novels from which I can enjoy reading, because the book is mine." (Student $\mathrm{B}$ ).

\section{Excerpt 8:}

"Yes, I have the desire to fulfill the reading source, but I prefer the electronic reading sources or e-books, for example the comics." (Student D).

Things such as the desire to read, personal fulfillment of reading sources, and the length of time to read in everyday life, these things can have an effect on one's reading habits. The following are excerpts from some respondents regarding their habit of reading English texts. Excerpt 9: 
"I claim that my habit of reading English texts is still minimal because I read Indonesian texts more often than good English texts." (Student A).

Excerpt 10:

"I claim that I do not have the habit of reading good English. It is still in the form of a process because I have not routinely read English texts and must be improved further." (Student B).

Excerpt 11:

"I claim that I do not have the habit of reading good English, because I still do not read regularly. I also have a weakness, which is easily drowsy, unable to read with a long duration, and sometimes there are words/sentences that I do not know the meaning." (Student C).

\section{Excerpt 12:}

"I claim that I already have a habit of reading good English, because I get more information from reading. Especially in reading sources in the form of comics with English subtitles." (Student D).

Based on the claim of the respondents, most of them do not yet have the habit of reading good English. It made researchers ask about their plans for their routine reading English texts. Here are the responses from some respondents:

\section{Excerpt 13:}

"I really want to read English texts regularly, therefore; I have a plan to read regular English texts. Because I am aware that my vocabulary is still very minimal and my study in English Education department makes me have a sense of responsibility for these stereotypes." (Student A).

\section{Excerpt 14:}

"Of course I have a plan to read English texts regularly by making a schedule I can implement. For example, it has been scheduled to read English text 3-5 times a day." (Student B).

\section{Excerpt 15:}

"I have a plan to read regular English texts, taking the time to read before going to sleep, after waking up, or when I have free time." (Student C).

This shows that most of them have a plan to be able to read English texts regularly because they believe regular reading of English texts is very important and influential for their academic achievement.

The analysis of the results of this study states that students majoring in English Education have positive beliefs about reading English texts. By reading English text they believe they can improve their skills and knowledge in English and support the success of their studies and careers in the future. However, many of the respondents did not have good habits in reading English texts. This is proven by the fact of research conducted by researchers by interviewing several respondents, that many of them do not read English texts every day. This becomes a reflection that reading English texts is not their habits. The biggest reason respondents do not have the habit of reading English texts regularly is because they have not spent most of their time reading English texts. The respondents have not been able to set aside the time wisely to read English texts, and there is a lack of interest in the topics or 
reading content provided by the lecturers. Researchers conclude, that these are the things that really hinder respondents from reading In general, the pattern of teaching reading in schools is uninteresting and boring, this is in line with the research of Owusu-Acheaw and Larson (2014) that students should be recommended to read magazines instead of reading textbooks all the time. Students reading magazines function to cool their brain and avoid mental fatigue and also make them disciplined life at school. This implies that learning English, which starts from the play group level to college or at least 12 years of compulsory education, does not guarantee a strong stance on the habit of reading English texts for students of the English Education department.

Therefore, pre-service English teachers need to make plans in teaching reading, so that good reading habits can be realized, such as the Morning Reading Session (MRS) as part of Uninterrupted Sustained Silent Reading (USSR), to foster good reading habits (Iftanti, 2012). Reported in Iftanti (2012) that to foster reading habits they can find time to read casually. This shows that those who read as pleasure in a relaxed time can have a positive impact on their reading habits. This study is also in line with the research of (Lin et al., 2012) which has proven that students with self-efficacy are very important in learning all languages, especially in L1 and L2, because with high self-efficacy can increase trust self and positive attitude towards language learning. Therefore, those with high self-efficacy have sought to approach success.

Through research conducted by researchers, it turns out that the high level of self-confidence of respondents in completing academic studies can lead to success. This research has proven with the motivation of students of the English Education Department, they can carry out the practice of reading English easily, because their motivation will result in enthusiasm for reading. This has a positive impact, one of which is increasing their ability and knowledge in English, such as adding insight into vocabulary when reading. Although they like to read various English texts, it turns out that only a few read English texts for pleasure or to spend their free time. Whereas reading English texts for pleasure is assumed to be an indicator of the habit of reading English texts which will have a positive impact, as in the research of Owusu-Acheaw and Larson (2014) that after taking formal education, some people like reading as their hobby. The goal is to broaden the reader's horizons. The practice of reading as a hobby helps a person become versatile knowledge in many fields and the person can discuss problems knowledgeably with others.

The purpose of readers who want to broaden their horizons in the fields of education, religion, politics, economics, the present stories, fiction and nonfiction (Owusu-Acheaw and Larson, 2014) in line with this study which shows that this English Language Department student has a strong desire to meet the reading source. In addition to reading sources, the habit of reading English texts requires the role of lecturer/teacher. Students of the English Education department agree that one of their biggest motivations is reading English-language texts is because their instructors support to read. In line with the results of Akarsu and Dariyemez (2014) research, teachers are effective in developing student reading habits. Educators must instruct students to improve their reading habits. Educators must also learn about effective methods to develop the reading habits of English Education department students.

This study confirms that students of the Department of English Education who have developed well in the habit of reading English puzzles are those who always read English texts regularly. Interest is a very important element because it is the basis for doing something. Without interest, such as getting used to reading English texts, it will never materialize. Then, the control felt by students to choose their own books or important reading sources as stated by Owusu-Acheaw and Larson (2014) that reading will have a more positive impact, such as adding insight and being able to develop themselves, if reading is done in a fun way. Thus, students of the English Education department who are less interested in the reading resources provided by lecturers, it is better to determine what kind of 
text to read to foster a habit of reading English texts within themselves. The next is selfefficacy. This study also reveals that the high level of self-confidence of students in the English Education Department indicates that the English Education Department students have good self-efficacy. The last is involvement. The involvement of English Language Department students in reading is marked by the amount of time or time spent for reading books or articles. Unfortunately, they have not dedicated much of their time to reading, so at the time of the interview many of them claimed that they did not have the habit of reading good English texts. Therefore, it is necessary to take firm action regarding the time set aside to read English texts every day, so that this becomes a good habit.

\section{Conclusion}

This study comes to the conclusion that pre-service English teachers do not show good English reading habits, even though they have studied English for approximately 12 years. The length of time studying English does not guarantee the development of a good habit of reading English texts. There are still many pre-service English teachers who do not routinely read English texts. This is one of the causes of obstruction to a good reading process. Therefore, it is necessary to repeat regularly every day; therefore, reading English texts becomes a habit. This routine repetition requires internal motivation to run well, especially in self-efficacy. With a good ability to read English texts, pre-service English teachers will have extensive knowledge and good and creative English language skills. This will become a provision for teaching later, so that teaching English is not monotonous but also creative. Good reading skills will be created due to good reading habits. This study demonstrates a positive belief among students majoring in English education that they have goals to achieve as prospective pre-service English teachers. The general objective is to improve knowledge and skills in English. The need for further research on effective ways to improve the reading habit of English texts for pre-service English teachers will complement this present study.

\section{References}

Akarsu, O., \& Dariyemez, T. (2014). Investigating ESL/EFL students' approaches in response to revision processes: A case study. Journal of Language and Linguistic Studies.

Annamalai, S., \& Muniandy, B. (2013). Reading Habit and Attitude among Malaysian Polytechnic Students. International Online Journal of Educational Sciences.

Chettri, M. K., \& Rout, S. K. (2013). Reading habits - an overview. IOSR Journal Of Humanities And Social Science.

Danandjaja, J. (2014). Metode Penelitian Kepustakaan. Antropologi Indonesia. https://doi.org/10.7454/ai.v0i52.3318

Dewi, A. A. I. B. F., \& Prawita, N. K. R. D. (2019). IMPROVING YOUNG LEARNERS' INTEREST IN READING. Yavana Bhasha: Journal of English Language Education. https://doi.org/10.25078/yb.v2i2.1025

Etikan, I. (2017). Sampling and Sampling Methods. Biometrics \& Biostatistics International Journal. https://doi.org/10.15406/bbij.2017.05.00149

Gambrell, L. B. (2015). Getting Students Hooked on the Reading Habit. Reading Teacher. https://doi.org/10.1002/trtr.1423

Grabe, W., \& Stoller, F. L. (2012). Reading and vocabulary development in a second language: A case study. In Second Language Vocabulary Acquisition. https://doi.org/10.1017/cbo9781139524643.009

Heale, R., \& Twycross, A. (2018). What is a case study? In Evidence-Based Nursing. https://doi.org/10.1136/eb-2017-102845

Iftanti, E. (2012). A SURVEY OF THE ENGLISH READING HABITS OF EFL 
STUDENTS IN INDONESIA. TEFLIN Journal. https://doi.org/10.15639/teflinjournal.v23i2/149-164

Lin, D., Wong, K. K., \& McBride-Chang, C. (2012). Reading motivation and reading comprehension in Chinese and English among bilingual students. Reading and Writing. https://doi.org/10.1007/s11145-011-9297-8

Owusu-Acheaw, M., \& Larson, A. G. (2014). Reading habits among students and its effect on academic performance: A study of students of Koforidua Polytechnic. Library Philosophy and Practice.

Palani, K. K. (2012). Promoting Reading habits and creating literate society. Journal of Arts, Science \& Commerce.

Pehlivan, A., Serin, O., \& Serin, N. B. (2010). Determining reading interests and habits of candidate teachers (TRNC Sample). Procedia - Social and Behavioral Sciences. https://doi.org/10.1016/j.sbspro.2010.12.251

Ramírez Salas, M. (2011). English Teachers as materials developers. Actualidades Investigativas En Educación. https://doi.org/10.15517/aie.v4i2.9087

Suryati, N. (2015). CLASSROOM INTERACTION STRATEGIES EMPLOYED BY ENGLISH TEACHERS AT LOWER SECONDARY SCHOOLS. TEFLIN Journal - A Publication on the Teaching and Learning of English. https://doi.org/10.15639/teflinjournal.v26i2/247-264 